\title{
UNIVERSITYOF
}

FORWARD

THINKING

WESTMINSTER用

WestminsterResearch

http://www.westminster.ac.uk/westminsterresearch

Understanding Russia's return to the Middle East

Dannreuther, $\mathbf{R}$.

This is an author's accepted manuscript of an article published in International Politics, DOI: 10.1057/s41311-018-0165-x, 2018.

The final publication is available at Springer via:

https://dx.doi.org/10.1057/s41311-018-0165-x

The WestminsterResearch online digital archive at the University of Westminster aims to make the research output of the University available to a wider audience. Copyright and Moral Rights remain with the authors and/or copyright owners.

Whilst further distribution of specific materials from within this archive is forbidden, you may freely distribute the URL of WestminsterResearch: ((http://westminsterresearch.wmin.ac.uk/)).

In case of abuse or copyright appearing without permission e-mail repository@westminster.ac.uk 


\section{Understanding Russia's Return to the Middle East}

Over recent years, there has been a significant resurgence of Russian power and influence in the Middle East which he been evident in the diplomatic and military intervention into Syria. This article identifies the principal factors behind this return of Russian power to the region. First, there are the domestic political influences with the coincidence of the uprisings in the Middle East, the so-called 'Arab Spring', with large-scale domestic opposition within Russia during the elections in 2011-12. Second, there is the role of ideas, most notably the growing anti-Westernism in Putin's third presidential term allied with Russia's own struggle against Islamist terrorism. These ideational factors contributed to the Russian resolve to support Syria against both Western intervention and its domestic Islamist opposition. Third, Russia has benefited from the flexibility of its economic, diplomatic and military engagement with the region which seeks to ensure that Russia is a critical actor for all the various states and political movements in the region.

Keywords: Russia, Middle East, Syria, Intervention, Arab Spring.

Biography: Roland Dannreuther is Professor of International Relations at the University of Westminster. His research interests include security studies, energy security, and the regional and international politics of Russia, Central Asia and the Middle East. Recent publications include Energy Security (Polity 2017), International Security: the Contemporary Agenda (Polity 2013), Global Resources: Conflict and Cooperation (Routledge 2013) (co-edited with Wojciech Ostrowski); China, Oil and Global Politics (Routledge 2011) (co-authored with Philip Andrews-Speed), Russia and Islam: State, Society and Radicalism (Routledge 2010) (co-edited with Luke March).

Looking back at the year 2017, Russia's position in the Middle East appeared stronger, more active and diplomatically central than could have been scarcely imagined a few years earlier. In Syria, the Assad regime, which had looked on the brink of military and political defeat, had been stabilized through Russian military intervention and Russia had gained broad regional recognition as the most influential external power seeking to negotiate a resolution of the conflict. Russia also managed to have strong diplomatic relations with both Iran and Israel, despite their mutual antipathies. After a brief period of antagonism and diplomatic rupture in 2016, economic and political relations with Turkey were restored with an increasingly positive and warm relationship developing between President Vladimir Putin and his Turkish counterpart, Recep Tayyip Erdogan. Russia also restored close relations with one of its oldest allies in the region - Egypt - after many years of estrangement. Even with Saudi Arabia and the Gulf states, Russia had made many inroads despite the historical legacies of mutual distrust. In September 2017, Saudi Arabia's King Salman bin Abdulaziz Al Saud made the first official visit of a ruling Saudi monarch to Moscow.

All of this certainly adds up to a significant resurgence of Russian power and influence in the Middle East. After the collapse of the Soviet Union, and arguably for a number of years before this, Russia had effectively become a marginal power and its voice was limited and constrained. This was a period of US hegemony, acting as a unipolar power, and involved the most ambitious expansion of US military power, 
most notably with the first Gulf War (1990-91) and the second Gulf War (2003). In both these wars, Russia was not influential in the diplomacy leading to these conflicts and played no role in their execution. In terms of its own diplomatic priorities, the Middle East was much less important than relations with the US, Europe and China and much less politically critical than relations with the newly independent states on its borders, the so-called 'near abroad'. During the 1990s, the disengagement was evident in the fact that President Boris Yeltsin made no official visits to the region. This changed in the mid-2000s when his successor, President Putin, engaged in a diplomatic flurry of activity, visiting Egypt, Israel, Saudi Arabia, Jordan, Qatar and the United Arab Emirates in the period from 2005-7 (Oliker et al., 2009; Dannreuther 2012). Nevertheless, despite this higher regional profile, Russia was still considered primarily as an irritant to Western dominance, most notably through its support of Iran's civilian nuclear power ambitions and in providing sales of military weaponry. Overall, Russia was more focused internally on the need for economic development than externally on geopolitical adventurism in the Middle East.

This relative disengagement was to change significantly with Russia's response to the Arab Spring. These political uprisings started in Tunisia and Egypt in 2011 and then spread across the region, threatening the longstanding authoritarian regimes in the Arab world. Understanding the reasons why Russia responded in the way that it did to developments in the Arab Spring, and by so doing gaining its current revived status as a major power in the region, is the main purpose of this article. Following the analytical framework of this volume, three distinct factors will be analysed: domestic influences, the role of ideas, and power considerations.

First, it is argued that it was the coincidence of the Arab Spring with the Russian electoral cycle in 2011-12 that was a critical factor in buttressing Russia's determination to re-deploy its diplomatic, economic and military power in the region. This was most notably evident through its unwavering diplomatic backing of the Assad regime in Damascus, despite the strong countervailing regional and international forces supporting the dictator's overthrow. It was the subsequent Russian annexation of Crimea and the intervention into eastern Ukraine in 2014 resulting in Western-imposed sanctions on Russia that provided the context for the Russian escalation to active military intervention in Syria on the side of the progovernment forces in autumn 2015. Although retrospectively it can seem that this Russian strategy was destined to be successful, the extent of calculated risk that this involved at the time, particularly in the context of a position of regional and international isolation, should not be underestimated.

Second, the role that ideas played in contributing to Russia's expanded engagement in the region is important but also a rather more complicated factor. PostSoviet Russia does not have an overarching ideology such as Soviet MarxistLeninism and a division of the world into reactionary and progressive forces. It also does not subscribe to a Western liberal ideological vision of democratic and nondemocratic forces playing out on the international arena. Indeed, the 'Russian idea', as developed under Putin's rule, adopts an essentially conservative and reactionary approach which critiques the perceived imperialism and destabilization of Western liberal interventionism and the support given to 'regime change' and democratization. In the Middle East, this political illiberalism combines with a more complex set of ideas of the sources of stability in a region where Islam is an integral part of the 
religious, social and political environment. This Islamic dimension is linked to the idea of Russia itself as a multi-confessional state that incorporates a substantial Muslim constituency, and which has suffered from the effects of Islamic extremism and terrorism. Putin's worldview and his understanding of the Muslim world is significantly affected by his experience of dealing with Chechnya and the Islamist insurgency in the North Caucasus, and this contributed to decision-making over the intervention into Syria.

The third part of the article show how these domestic and ideational factors interact with the more messy realities of the shifting power dynamics and complex inter-relationships in the Middle East. It should not be forgotten that Russia has a long history of interaction with the Middle East and knows that political relations with actors in the region are fickle and tend to be short-lived. Even during the Soviet period, Moscow struggled to find reliable allies in the region. Post-Soviet Russia has few illusions about this and prides itself on being non-ideological in the sense of not seeking to promote revolutionary changes and instead adopting pragmatism and realpolitik as key elements of its policy and the necessary conditions for its success. In this sense, Russia has played its economic, political and diplomatic cards astutely, seeking to ensure that all states in the region, whatever their ideological hue, view Moscow as an essential regional interlocutor. However, in a region where local actors have a long history of playing off their competing external patrons, what has metaphorically been called the 'tail wagging the dog' phenomenon, this provides fragile foundations for the durability of the longer-term power and influence of Russia in the region.

\section{The Arab Spring and Russian Domestic Factors}

The initial eruption of popular protests in Tunisia and Egypt in late 2010 and early 2011 did not lead to any particularly strong negative reactions in Moscow as they did not appear to present a significant threat or disruption to Russian interests, given the relatively limited economic and political ties with these two countries. The Russian leadership was also keen at this stage not to be viewed as denying the legitimate democratic aspirations of the Arab world. Putin himself affirmed that the social dynamics resulting in the Arab Spring were both positive and necessary and the 'sympathies of the Russians were on the side of those struggling for democratic reforms' (Putin 2013). Among Russian analysts, there was a recognition that the Arab authoritarian regimes had been in power for too long and had become corrupt and had failed to reflect the changing nature of their societies (Ivanov 2013a: 8-32). The Russian leadership pragmatically recognised the overthrow of Hosni Mubarak in Egypt in February 2011 and agreed to work with the new Muslim Brotherhood government under the leadership of Muhammad Morsi.

Nevertheless, the Russian interpretation of the developments in the region was markedly different to the dominant Western narrative. While most Western commentators and popular Arab sentiment were generally optimistic that a new era was dawning and that a decisive shift towards democracy was occurring, Russian views were more cautious and pessimistic. Instead of an inexorable process towards democracy, the dominant Russian analysis was that the Arab Spring represented a return to the traditional values of Middle Eastern societies, incorporating a stronger Islamic identity, rather than a shift to a Western-style democracy. The narrative was 
thus couched primarily in terms of Islamization than of democratization. While there was a recognition that an inevitable transformation was taking place and there was a historical logic to it, this change was not viewed through the prism of Western-style democracy but in terms of a broad-based societal yearning for a more authentic and traditional Islamic identity. This passing of an old order was viewed with some nostalgia and wistfulness by some Russian commentators. One senior Russian diplomat noted that what was happening was a shift of power from the Sovieteducated secular leftist Arab generation to a younger Islamist generation that has less affection and more limited ties with Russia (Lukmanov 2013).

This rather low-key, passive and even fatalistic response might potentially have continued if these developments in the Middle East had not become intertwined with developments inside Russia itself. The period 2011-12 was one of unprecedented internal domestic Russian political contestation and intra-elite conflict. One underlying cause of this was the global recession of 2008-10 which had contributed to the collapse of oil and gas prices and had resulted in a severe recession in the Russian economy. This represented a major challenge for the popularity and legitimacy of the Russian leadership as it had greatly benefited electorally from the increased prosperity brought about by the commodities boom which had started with Putin's ascent to power in 1999 (Rutland 2008; Bouzarovski and Bassin 2011). With the preparations for the 2011-12 parliamentary and presidential elections, the economic record was not such a clear electoral advantage for the incumbent regime (Hutcheson and Petersson 2016: 1116-7).

This fed into the more general political instability which had its roots in the decision in 2008 by Putin to abide by the constitutional term limit of two consecutive presidencies and to support his hand-picked successor, Dmitrii Medvedev, to the post while nevertheless remaining a powerful prime minister. By 2010-11, there was widespread political speculation in Russia about what would happen to this 'tandemocracy' when its term came to an end and whether a genuine electoral competition would be permitted with Putin willingly relinquishing his power. This speculation was brought to an abrupt halt with the peremptory announcement in Spring 2011 that Putin and Medvedev would again swap jobs and Putin would have a third term as President. For many Russians, particularly the more liberal urban middle classes, this was a deeply cynical move and mounted to what Richard Sakwa has called a 'constitutional coup' (Sakwa 2014: 116). While it did not explicitly contravene the letter of the law, there was outrage with the presumption that the Russian public would just meekly accept this political manipulation. With subsequent evidence that then emerged of significant vote-rigging in the 2011 parliamentary elections, this resulted in the largest public protests for over two decades in the winter of 2011-12. This contributed to a sharp decline in both Putin's and Medvedev's popularity (Hutcheson and Petersson 2016: 1111).

Although officially Medvedev and Putin presented a common and unified political stance, there were nevertheless differing economic and political priorities and tensions between them. Medvedev's distinctive response to the economic crisis was to promote a vision of economic modernization which required political reform. He established a think-tank, the Institute for Contemporary Development (INSOR), which articulated the need for democratic reform so as to reduce 'policy mistakes', to improve 'human capital' and engage with society so as to reduce political protests, 
and the need generally to counter corruption and to protect citizens from arbitrary bureaucratic interference (INSOR 2010: 10-11). While not rejecting these proposals, Putin did not himself explicitly endorse them and remained above the political fray, leaving it open which way he would ultimately go. Nevertheless, it was implicitly clear that his stance reflected a caution that such moves could potentially undermine the charismatic foundations of his authority and popularity (Robinson 2017: 358). Another distinctive area of Medvedev's approach was his commitment to improved relations with the United States. After the deterioration of bilateral relations due to the 2008 Russian military intervention into Georgia, Medvedev embraced the 'reset' agenda promoted by the Obama administration. This led to a number of gains, including the conclusion of the New Start Treaty that cut nuclear arsenals and Moscow agreeing to impose sanctions on Iran's nuclear programme. Again, while Putin outwardly supported this political rapprochement, his stance was more conditional and was not linked to the modernization agenda that Medvedev promoted.

It is at this political juncture that developments in the Arab Spring crucially interacted with these domestic political dynamics and tensions within Russia. The general linkage between pro-democracy popular opposition in the Middle East and the protests occurring in Russia had already been picked up by Russian commentators and opposition forces (Sokolov 2011). However, it were the specific developments in Libya that raised the first major challenge for Russian diplomacy as, in contrast to Tunisia and Egypt, the Libyan regime did not capitulate to the demands of the opposition, but rather threatened brutally to crush that opposition. The dilemma for Russia was whether it should support a Western-sponsored resolution at the UN Security Council which sought to provide protection for Libyan civilians under threat from Gaddafi's forces. Medvedev was inclined to back the Western initiative believing it was critical to preserve the 'reset' agenda, which promised support for Russian entry into the WTO and a new START treaty (Suslov 2012). However, the Russian Foreign Ministry recommended vetoing the resolution. Vitalii Churkin, the Russian permanent representative to the UN, explicitly warned about the 'inclusion of provisions in the document that potentially open the door for large-scale military intervention' (Grigoriev 2011). The eventual compromise was that Russia abstained from Resolution 1973. Once the resolution was passed, NATO initiated air strikes and provided military support to the opposition, leading to the overthrow of the Libyan regime and the execution of Muammar Gaddafi.

The decision not to veto this resolution was immediately challenged by Putin. He was then still prime minister and argued that the resolution was 'deficient and flawed' and that it 'allows basically anyone to do anything that they want - to take actions against a sovereign state. Basically, all that this reminds me of is a medieval appeal for a crusade' (Ivanov and Kozlov 2011). Medvedev responded immediately by saying that it 'was absolutely inexcusable to use expressions that, in effect, lead to a clash of civilisations - such as 'crusades' and so forth' (Demchenko 2012). Although at the time some commentators interpreted this exchange as a stage managed difference of opinion between the two leaders (Samarina 2011), it is clear in retrospect that this internal dispute was a critical turning point when Medvedev's ambition for a second presidential turn, based on a pro-Western modernization agenda, was decisively weakened. The subsequent NATO air strikes in support of the Libyan opposition, and the decapitation of the Libyan regime, were a major 
embarrassment for Medvedev and shifted elite support and public popularity towards Putin (Suslov 2012).

The Western action in Libya, and in particular the gruesome fate of Gaddafi, appears to have deeply affected Putin as an exemplar of Western duplicity and illegality, regularly appearing in subsequent speeches (Stepanova 2016). It confirmed for him, first, that the Arab Spring was going badly wrong and that 'instead of the affirmation of democracy, instead of defending the rights of the minority, there was increasingly the expulsion of the enemy, coups d'état, where the domination of one side becomes an every aggressive domination of the other' (Putin 2012). For its part, the West was deemed to be a major catalyst for these negative developments as they 'were made worse by intervention from outside in support of one side of the conflict and the forceful character of that intervention. It led to a number of governments under the cover of humanitarian interventions and with the aid of air power dividing the Libyan regime. And the apotheosis of this was not even a medieval but simply a brutal elimination of Muammar Gaddafi'. The logical consequence of this for Putin was that 'we must not allow the 'Libyan Scenario' to be attempted to be reproduced in Syria' (Putin 2013).

It was this strident and even emotional response that underlay the subsequent resolve to take the necessary calculated political risks of strongly upgrading the economic, diplomatic and military support to Syria. Support for Syria became a larger issue than simply support for a loyal ally but, as Sergei Lavrov, the Russian foreign minister, argued 'the way the Syrian crisis is resolved will largely determine the model for the international community's response to internal conflicts in the future (Chernenko and Yusin 2012). This support for Syria initially took the form of Russia exercising its power of veto in the UN Security Council to block the imposition of sanctions or the authorization of military action against the Syrian regime. In so doing, Russia was willing to be diplomatically isolated to an unprecedented degree, with its sole ally often being China. In the period from 2011-14, Russia also provided military support through the provision of 'defensive weapons', the sending of military advisers to support the regime's forces, and intermittent displays of military power projection, such as the patrolling of Russian warships close to the Syrian shores as well as using the Russian base in the Syrian port of Tartus (Allison 2013). Although Russian policymakers were aware of the potential risks of this strategy, not just in alienating the West but also a number of major regional powers, such as Turkey, Saudi Arabia and Qatar who supported the anti-Assad opposition, this was counterbalanced by the calculation that the West and its allies lacked the political stomach for the scale of military intervention that would be required to dislodge Assad and his regime. Russia's diplomatic success to avert Western military action in response to the Syrian regime's use of chemical weapons in 2013, which the US President Barack Obama had earlier asserted to represent a 'red line' which would trigger such intervention, exposed the doubts and anxieties lying under the surface of much elite and popular thinking in the US and Europe (Gerges 2013: 308-12).

It is not clear to what extent the appearance of Western timidity in Syria in 2013 emboldened Russia to annex Crimea and militarily to intervene in Eastern Ukraine in 2014. It is generally likely that it was only a marginal factor. Nevertheless, the subsequent severe deterioration in Russian-Western relations, which included the imposition of sanctions, undoubtedly increased the appetite for risk in Russia's Syrian 
strategy. In September 2015, this led to direct Russian military engagement through air strikes in support of the Assad regime. What was new in the aftermath of the Ukraine crisis was Putin's greatly increased conviction that Russia was now suffering a deliberate policy of containment and that this 'containment was not invented yesterday. It has been applied to our country for many, many years ... Every time when anyone only thinks Russia has become strong, independent, such instruments are applied immediately' (Putin 2015). Putin's actions to escalate the Russian engagement in Syria in 2015 have historical parallels with Nikita Khrushchev's decision in 1955 to 'leap-frog' the wall of containment through sanctioning the Czechoslovak arms deals with Egypt and Syria, which was a key landmark in the Soviet Union's earlier 'return' to the Middle East (Trenin 2018: 21).

The important point here is that this strategy towards Syria directly supported Putin's resolve to strengthen his domestic base of support and thereby contribute to regaining the levels of popularity which he had traditionally enjoyed. During his third term as president, the modernizing and implicitly pro-Western strategy that Medvedev had sought to articulate was jettisoned for what has been called Putin's 'cultural turn' (Robinson 2017). Internally this has meant ceasing to craft a message which directly incorporated the interests of the liberal and modernizing segments of Russian urban society but rather one which consolidated support among the rural and industrial heartlands through a return to 'traditional values'. This involved marginalizing liberal elements in Russian society and, at the extreme, treating them as a potential Westerninfluenced and a treacherous 'fifth column'. Externally, this was manifested in a return to exerting a traditional Russian great power projection, which was willing to take the steps necessary to preserve Russian interests in Ukraine and to restore Sovietstyle Russian prestige in the Middle East. By 2014, Putin's personal approval had soared to $80 \%$, a figure that was a historical high for all his time in office, moving from as low as 30\% in early 2012 (Levada 2015).

\section{Ideational Factors: State, Society and Islam}

As is evident in the analysis so far, Putin and the Russian leadership have strong and clearly expressed views about the nature of political and international order and the appropriate role of state, society and religion in supporting and underpinning this order. However, whether this adds up to a distinctive ideological vision which can be said to underpin Russian foreign policy and also has a strong attraction for external actors is more problematic. If one means by ideology a progressive normative vision, which seeks significantly to change the world, such as Soviet Marxism-Leninism or liberal internationalism, then the official 'Russian idea' does not represent a clearly defined ideology. Indeed, Russian leaders and commentators regularly assert that there is no such overarching ideology. Sergei Ivanov, a key political ally of Putin, affirms this image of an essentially pragmatic and non-ideological Russia by stating that 'we don't export ideology any more - we only export goods and capital' (Ivanov 2008). Despite such protestations, the 'Russian idea' promoted by Putin, particularly with his more recent 'cultural turn', does have a substantive content. But it is of an essentially reactionary nature, seeking to buttress and support state power and incumbent regimes against the forces of countervailing ideological pressures and threats. As such, these ideas are attractive only to the extent that they are essentially undemanding, at least for the authoritarian regimes dominant in the Middle East, with 
no requirement, for example, for political conditionality related to human rights or democratic governance.

Putin's conceptualization of political order is primarily reactive to what he sees as the main antagonistic and negative ideological forces in contemporary international affairs. Andrei Tsygankov (2013) has usefully identified these as the twin threats of 'Westernism' and 'Islamism'. The ideological response to these two perceived threats has an intellectual component but of greater salience is Putin's own experience and perceptions of their malign impact on post-Soviet Russia. In terms of 'Westernism', the threat is conceived as an amorphous amalgam which spans the liberal opposition in Russia, the coloured revolutions in the post-Soviet states, NATO enlargement, humanitarianism and Western-imposed regime change in the Middle East and elsewhere. The intellectual spadework for a distinctive Russian critique of this hydra-headed ideological threat was undertaken by Vladislav Surkov with the development of the concept of 'sovereign democracy' (Surkov 2006). The core of this concept is a rejection of liberal pluralist conceptions of democracy, at least in modernising states that are in the process of transition and democratic reform, since it requires the division of society into differing factional groups which is, it is argued, inherently destabilising. For Surkov and other Russian elites, the danger is that, in Russia as well as other countries with a differing historical and political culture, the promotion of a Western-style pluralistic concept of the state can only lead to internal disorder, societal conflict and the loss of the 'sovereign' integrity of the state (Averre 2009: 1697). What, in contrast, is required is for the state to take the primary role in managing the transition to democracy, ensuring that the resulting societal transformation does not lead to disorder and conflict but preserves social stability and economic development.

For Putin, this strongly statist and anti-liberal ideological stance is intimately connected to his experience of what he sees as the West's post-Cold War triumphalism with the export of the ideology of pluralist democracy in the guise of humanitarianism. For Russia, this involved a series of humiliations, ranging from the disintegration and degradations of post-Soviet Russia in the 1990s to the containment of Russia through NATO and EU enlargement. On a broader international level, Western unilateralism is seen to have progressively undermined the foundations of the United Nations as the guarantor of international order, based on the principles of nonintervention and political independence (Deyermond 2016). In this worldview, the impact of Western-promoted liberal interventionism has been a series of military actions to topple 'illiberal' regimes around the world that have had severe negative effects, creating the conditions for civil war, anarchy and conflict. This has been particularly evident in the Middle East where the large-scale military interventions in Iraq, Afghanistan and Libya have led to serious deterioration of their internal stability and endemic civil conflict. It is here that Russian analysts view the West as indirectly responsible for the spread of Islamist extremism by providing the conditions in which such extremism thrives. In this broader context, the Russian intervention into Syria was conceived both as a deliberate counteraction to this Western quasi-imperialist drive for domination and as setting a new paradigm for how political change should be managed in the region and elsewhere in the world.

This strong anti-Western rationale for the intervention into Syria, however, is mitigated and qualified by the recognition that, in relation to the second of the twin 
threats, Islamism, the West is understood to be a strategic ally of Russia, if also, as noted above, sometimes tactically unreliable. Russia has suffered, similar to the US and many European countries, the effects of Islamist-inspired terrorism. Indeed, for Putin the struggle against the Islamist insurgency in Chechnya and in the North Caucasus was a defining feature of his ascent to power and a source of his enduring popularity. In contrast to the vacillations of the Yeltsin years, which led to the creation of a de facto autonomous Islamic republic in Chechnya, Putin responded with a sustained and unremitting military campaign, a policy of no negotiations with terrorists, and the provision of unstinting support for the corrupted and authoritarian but nevertheless effective Chechen political leadership. This experience in Chechnya has undoubtedly influenced the political and military support provided by Russia to the Assad regime and its military campaign. Russia has turned a blind eye as well as been directly implicated in indiscriminate aerial assaults on civilian targets to secure territorial gains for the Assad regime. Moreover, it is estimated that over 3,000 Russian citizens have gone to join the Islamist forces in Syria since 2014. This means that there is a direct perceived linkage between Russian actions there and domestic stability at home (Fitzpatrick 2016).

At the same time, the Russian leadership has been keen to make clear the distinction between such Islamist-inspired terrorism which must be eliminated and Islam as a religion which must be respected. Despite Putin's 'cultural' turn and his increasing reliance on more populist and charismatic sources of legitimacy, he has never supported a nationalist particularism. He is very disdainful, for example, of the ethno-nationalist call for a Rossiya dlya russkykh (Russia for ethnic Russians) and views such exclusivist nationalism as dangerous as its antithesis of liberal cosmopolitanism. For Putin, Russia is a 'state-civilisation' rather than a 'nation-state' and a state that has historically incorporated and protected the different traditional faiths and confessions, including Islam (Fish 2017: 66; Tsygankov 2016). Indeed, he treats Russian Muslims as full partners of the Russian national community. In this vein, Vitaly Naumkin, the Director of the Oriental Institute, argues that the indigenous Tatar Muslims should rightly be considered as 'co-constructors of the Russian state' (Naumkin 2006). This narrative of Russia as being tolerant of religious, ethnic and confessional diversity, however problematic it might be in strictly historical terms, is one that Russian policy makers seek to capitalize in their interaction with the Middle East. As one influential Russian report argues, Russia's advantage in the Middle East is that it 'comes across as a civilisationally close state, in a significant measure belonging to both Europe and Asia, the Christian and Islamic worlds, and not expressing to the world European 'hyper-secularism' which is not welcome to Middle Eastern societies, particularly in the post-Spring period' (Ivanov 2013b: 24).

Nevertheless, this idea of Russia as a beacon of toleration and Muslim inclusion is inevitably challenged by the intensity of its repression of Islamist insurgencies, whether in Chechnya or in Syria, which for many Muslims can appear as undifferentiated and problematic as Western policy. To counter this, an important further distinction made by Russian policymakers, first articulated by the orientalist and former foreign minister, Yevgeny Primakov, is between Islamic 'fundamentalism' and Islamic 'extremism'. Primakov argued that Islamic extremism is unacceptable and needs to be repressed at all cost. Indeed, Putin makes a point, in contrast to US President Donald Trump, of never talking about 'Islamic terrorism' but 
only of terrorism and insists that the Russian media always describes ISIS as the 'socalled Islamic state'. In contrast, Primakov argued that Islamic fundamentalism should be recognized as being an entirely legitimate expression of Islamic faith, indeed even as a description of true Islamic faith, and that the only condition of the political legitimacy of 'fundamentalist' Islamic movements or states is whether they are willing to engage in the political process (Dannreuther 2010: 15). This more expansive definition has made it possible for Russia to be much more willing to engage with Islamic states and movements that the West considers as terrorist or as internationally illegitimate, such as Iran, Hamas and Hizbullah. Although this does not square all circles in terms of Russia's inclusiveness, since regional powers like Israel and Saudi Arabia certainly do not welcome such diplomatic openness to forces that they see as their mortal enemies, this political stance nevertheless gives a degree of flexibility for Russian diplomatic manoeuvring in the region.

\section{Power, Interests and Flexibility}

Such flexibility is the final key element which completes the picture of Russia's return to the Middle East. The focus of this article has so far been predominantly on Russia's engagement in Syria. After all, the Syrian question has dominated Russian policy and been the key catalyst for Russia regaining its voice and influence in the region. However, it is important to put this into perspective. Even in Syria, the military intervention only involved a relatively small force, estimated to be around six thousand at its height, which is smaller than the combined US forces based in Iraq and Syria, and only involved air strikes with no ground offensive. With the relative stabilization of the Assad regime, Russia has been energetic in seeking to drive forward a political settlement, and avoid the danger, very present in Russian thinking, of becoming trapped in the Syrian quagmire. The forceful intervention in Syria is also the exception rather than the rule for Russian involvement in the region. Russia has generally remained studiously neutral and cautious in the multiple other conflicts in the region. While being open to its inclusion as a mediator, it has not taken decisive positions or shown a willingness to intervene directly in the civil war in Yemen; it has been marginal in the continuing Israeli-Palestinian conflict; it has not wanted to get involved directly in the anti-ISIS campaign in Iraq; and despite its protestations over the removal of Gaddafi, it has supported both sides in the internal Libyan conflict. Overall, Russia has wanted to demonstrate its capacities as a disinterested interlocutor but has resisted making commitments beyond that of broad diplomatic engagement.

The preference for a generally cautious and pragmatic approach reflects an acute awareness among Russian policy-makers of the often swift and unexpected shifts in the relative distribution of power in a region notorious for the complexity of its intra-regional and international politics. Steeped in a realist and realpolitik tradition, Russia acts with a firm assessment of the 'correlation of forces' at any one time, seeking continually to maximise its capacity for action at the lowest cost and with the greatest gain in terms of its interests. Speed and agility at responding to the opportunities that emerge are seen as critical for success. A good example of this is the success at restoring much stronger ties with Egypt, taking the opportunity to benefit from the military coup and the disillusionment of the new Egyptian leader, Abdel Fatah al-Sisi, with the US over its treatment of his predecessor, Mubarak, and the subsequent US delays to provide economic and military support to the post-coup 
leadership. Russian-Egyptian relations gained even more in strength when Cairo's post-coup relations with Saudi Arabia deteriorated over conflicts of policies in Yemen and Syria (Mandour 2016). In February 2015, Russia and Egypt agreed to a $\$ 5$ bn arms deal; joint military exercises took place later in the year; and in November 2017 there appeared to be an agreement that Russia could use air bases in the country close to the Libyan border (Fitzpatrick 2017).

Russia's economic interests in the region have also opened up significant opportunities. Although the Middle East is not generally a major market for Russia, there has been an increase in the volume of trade since 2012 and the region has become more significant as Russia seeks to diversify so as to compensate for the impact of economic sanctions. Some of the most important economic partners for Russia are also countries which are traditionally pro-American in their orientation. Turkey is a major trading partner, with Turkish construction companies strongly present in Russia, and Turkey being a major tourist destination for Russian citizens. Russia also has a strong interest in developing Turkey as an energy hub for Russian gas to supply not only the Turkish market but also as a route to Southern Europe (Baev and Kirisci 2017: 5-8). After the failure to get agreement on the South Stream project, the major Russian project to secure gas pipeline access to South Europe, this was superseded by the agreement to develop the Turkish Stream pipeline project in December 2014. The agreement was then confirmed, after the brief rupture in Turkish-Russian relations, in October 2016 at a summit between Putin and Erdogan. Putin has also expended considerable political capital in cultivating stronger relations with Israel, building on the increasingly influential former Soviet Jewish constituency. Moreover, Moscow has recognized that Israel represents a critical source of high-tech economic goods and expertise for the Russian economy (Borshchevskaya 2016). Benjamin Netanyahu, the prime minister of Israel, who has been a regular visitor to Moscow, has generally tolerated Russian actions in Syria as a moderating force against Iran and Hizbullah. Also, he did not join other Western countries in imposing sanctions on Russia over Crimea. Russian citizens have gained visa-free access to Israel and the country has become a major Russian tourist destination.

Russia's status as a major oil and gas producer is another key asset and core economic interest of Russia in the region. As Russia is not an importer of oil and gas from the region, the opportunities are more in terms of developing energy-related cooperation and economic diversification. For example, Lukoil, the largest and most internationally active Russian private oil company, has ambitious plans for the Middle East, aiming to have one quarter of its foreign projects in the region and currently has significant investments in both Iran and Iraq, including in the Kurdish-controlled northern Iraq. To counter the negative impact of Russia's actions against the Saudisupported Syrian opposition forces, there has been active Russian diplomacy to be cooperative in supporting Saudi-led initiatives to increase global oil prices. In a break from a longstanding Soviet-inherited policy of not engaging in measures to set OPEC production levels, Russia agreed to lead attempts to persuade non-OPEC countries to coordinate policies with OPEC and signed up to its own designated production quota (Barman 2017). Russia has also directed significant diplomatic activity to encouraging the Gulf states to make much needed investments in the Russian economy. The Russian Direct Investment Fund has entered into co-investment deals with a number of sovereign wealth funds in the Gulf region, including Saudi Arabia, 
the UAE and Qatar. They have invested in agriculture, infrastructure and a variety of commercial enterprises in Russia (Sladden et al., 2016: 7).

This flexibility and pragmatic accommodation of Russian interests with its desire to promote itself as a major influence and powerful external actor has, however, a number of areas of potential risk. This can be seen in its relations with Turkey and Iran. While currently Russia is enjoying a high level of engagement with both these key Middle Eastern countries, there is a long history of mutual enmity and distrust, going back not only to the Soviet period but also to Tsarist times. Despite the markedly improved relations, these deep historically engrained suspicions have been far from overcome. In relation to Turkey, there was a serious freezing of bilateral relations in November 2015 after the Turkish downing of a Russian jet on the Turkish-Syrian border. The diplomatic crisis represented a culmination of serious differences between Russia and Turkey over Syria, most notably over the question of Bashar al-Assad's removal. However, in June 2016 this rupture in relations was mended and Erdogan and Putin developed increasingly strong relations. This was after Russia had given full support for Erdogan in the aftermath of the Gulenist coup, contrasting with the more critical response from the US and Europe. The Turkish strategy towards the Syrian conflict also moved in Russia's direction as Ankara increasingly recognised that the Assad regime was not going to be quickly toppled, and that both the regime and the Russian diplomatic and military forces supporting it, needed to be engaged so as to limit the military successes of the Syrian Kurds. The containment of the Kurds has increasingly become the overriding strategic concern for Turkey (Katz 2016a). The fact that the US relied upon Syrian Kurdish forces to counter ISIS further propelled Erdogan to welcome Putin's embrace. In its turn, Russia turned a blind eye to Turkey's air and ground offensive against Kurdish forces in Afrin in January 2018. Nevertheless, despite this current confluence of interests, there is no guarantee that they will be sustained in the long-run and almost no likelihood that Turkey will shift from its military alliance with the US in NATO.

Russia's warm relationship with Iran is arguably more stable and less fragile than that with Turkey. This is, however, more due to the fact that Iran's international isolation means that it has fewer options than Turkey to balance against Russian influence. But it does not mean that there are no conflicts of interest between Russia and Iran (Katz 2016b; Trenin 2017). The Iranian leadership has continually been frustrated by Russia's support for UN resolutions that seek to counter Iranian nuclear proliferation. In Syria, Iranian and Russian interests differ subtly in many aspects and Iran has its own distinctive objectives, allies and strategic ambitions. While supporting Iran, Russia also seeks to to demonstrate that it is an external power which can limit Iran's strategic ambitions and thereby assuage the fears of countries like Israel, Saudi Arabia and other Gulf states. Iran's post-colonial sensitivities concerning Russia have also not dissipated and can be seen in its diplomatic rebuff to the Russian claim that it now had a right to use the Hamadan airfield as a base for its military actions in Syria, though this did not stop Russia quietly resuming use of this facility after this incident (Kozhanov 2016). Iran has also not hidden its ambition to be a competitor with Russia for supply of gas to Europe. More generally, one of the main interests of the Rouhani administration is to improve economic and political relations with the West. Moscow clearly understands that, if there is such an improvement, Russia's relative influence in the region would almost certainly decrease. 
In general, all of this demonstrates that Russia realises that its regional influence depends on maintaining a complex and delicate balancing act so that, while it might not satisfy all actors in the region, it manages to be seen as indispensable to as many of them as possible (Zvyagelskaya 2016). In terms of strengthening Russia's capacity to take this increasingly important mediator role, two developments have been particularly important. The first is the relative disengagement of the United States in the region. While it would be a mistake to exaggerate this disengagement, as conservative critics of the Obama administration have tended to do (Hannah 2016), the US has moved away from an expansionist neo-conservative period in its engagement of the 2000s, which might be called its phase of 'imperial overstretch' (Kennedy 1987; Barnes 2017). With this shift, Russia definitely benefited from Obama's reluctance to get militarily involved in Syria and the signal that this sent about US commitment to the region. But the return of Russia also required a second development which was the embrace of Russia's return to the region by the local Arab and non-Arab states. L. Carl Brown (1984) has called the Middle East the "most penetrated region' of the world. As such, it is a region where the local actors have habitually preferred to have multiple external powers present so as to maximise their strategic autonomy by playing off and manipulating these external forces. Following this logic, Russia has been welcomed back more for its power balancing effects than any ideological factors.

The flipside of this salience of power balances and shifts in the dynamics of Middle Eastern politics is that the current configuration, which supports Russia's ambitions, might change. This could happen, for example, if the Trump administration decided to take a stronger line against Iran and decides to step up its support of the anti-Iranian regional forces, such as Israel and Saudi Arabia. It might also come from China, if Beijing decides to assume a role in the region consonant with its economic interests and no longer effectively sub-contracts out to Russia the support for its broader political objectives. Russia also suffers relative to these other external powers in being economically weaker and thus not able to sustain many losses to its regional position. Russia simply does not have the resources, for example, for post-conflict reconstruction in Syria and will have eventually to turn to the West and China for this. It is, however, unlikely to receive these resources unless relations with the West improve. There is also the fact that, though the Arab Spring has resulted in a return of authoritarian rule in the Middle East that Moscow has capitalised on, the seeds of social, economic and political discontent remain in the region and the hopes for a freer and more democratic future have been far from eliminated (Ben-Ami 2016).

\section{Conclusion}

This article has sought to identify the principal factors that contributed to the resurgence of Russian power and influence in the Middle East. Following the overarching framework of this volume, focus has been placed on the interaction between three elements power, ideas and domestic influences. In the case of the Middle East, the article argues that domestic influences played a critical and even unprecedented role in the development of Russian policy. Moscow's engagement was greatly influenced by the interaction of the uprisings in the Middle East with the rising domestic opposition and protests in Russia during the period of the electoral processes in 2011-12. It was this coincidence of events that provided the catalyst for the 
strongly negative Russian reaction to the overthrow of Muammar Gaddafi in Libya, which in turn strengthened Moscow's resolve to consolidate its support for the Syrian regime. This foreign policy shift was promoted personally and energetically by Putin in order to strengthen his domestic base of support and secure his third term as president. Domestic factors can, therefore, be seen to have provided the initial conditions for the renewed Russian ambition to strengthen its voice and influence in the region and to act forcefully in Syria.

Ideas played also an important role in the success of Russia's return to the Middle East. Here, it is more the case that the essentially conservative and reactionary nature of the 'Russian idea', which has become even more embedded with Putin's 'cultural turn' and his promotion of traditional values and a more strident antiWesternism to support his domestic base, also resonated with the spirit of the 'counter-revolution' to the Arab Spring. The autocratic and military leaders that suppressed the popular uprisings in the region found Russia to be an increasingly reliable supporter and as having a similar outlook on the need to re-assert an authoritarian political order. Even leaders of countries who have traditionally been highly suspicious of Russian ambitions, such the Saudi Arabia, respect Russia's consistency and reliability, particularly given their lack of confidence in the US and its perceived vacillations and inconsistency. In addition, the essentially conservative nature of the 'Russian idea' allows Moscow to engage with practically all political forces and states in the region, except for those groups which are explicitly promoting a revolutionary Islamist ideology with recourse to terrorist violence. This article argues that this flexibility, in conjunction with Russia's traditional policy of realpolitik, has given Moscow a powerful advantage in maximising its influence and making the best of the limited resources that it controls.

This article argues, therefore, that the interaction of domestic factors, ideas, and, power have enabled and shaped the resurgence of Russian power and influence in the Middle East. However, if one takes a longer term historical perspective, it can be argued that it is the period of the two decades after the collapse of the Soviet Union, when Russia essentially withdrew from the region, which is the historical anomaly. Andrei Gromyko, the long-time Soviet foreign minister, regularly stated that the Soviet Union had direct interests in the Middle East as it was a quasi-regional power with borders close to the region. Tsarist Russia fought multiple wars with the Ottoman Empire and was similarly deeply engaged in the politics of the region. As such, there is a long historical pattern of Russian engagement in the region driven by the political logic of rivalry, competition for control, and the perceived need to avoid containment and encirclement. It is salutary to note that Russia first militarily intervened into the Syrian region in 1776, when it supported Arab leaders fighting against Ottoman rule, and even occupied Beirut for a six month period. A few years later in 1783, Russia made its first annexation of Crimea, marking a decisive shift in geopolitical power, ending the Ottomans monopoly of control over the Black Sea (Montefiore 2015). The striking parallels between these events and the latest annexation of Crimea and Russian military intervention into Syria suggests that there are more elements of continuity than radical change in Russia's return as a major power in the Middle East. 
Allison, R. (2013). Russia and the Syria crisis: Regional order and the controversy over regime change. International Affairs 89(4): 795-823.

Averre, D. (2009). Competing rationalities: Russia, the EU and the "shared neighbourhood": Europe-Asia Studies 61(10): 1689-1713.

Baev, P. K. and Kirisci, K (2017). An ambiguous partnership: The serpentine trajectory of Turkish-Russian relations in the era of Erdogan and Putin. Turkey Project Policy Paper, 12. https://www.brookings.edu/wpcontent/uploads/2017/09/pavel-and-kirisci-turkey-and-russia.pdf. Accessed 20 January 2018.

Barman, Y. (2017). The politics of oil: How Russia pursues its energy dream in the Middle East. Al Sharq Forum, 4 March. http://www.sharqforum.org/2017/02/24/thepolitics-of-oil-how-russia-pursues-its-energy-dream-in-the-middle-east/. Accessed 20 January 2018.

Ben-Ami, S. (2016). Russia's ephemeral Middle East alliances. Project Syndicate, 5 October. https://www.project-syndicate.org/commentary/russia-ephemeral-middleeast-alliances-by-shlomo-ben-ami-2016-10?barrier=accessreg. Accessed 18 January 2018.

Baev, P. (2015). Russia as opportunist or spoiler in the Middle East?. International Spectator 50(2): 8-21.

Barnes, J. (2017). The Middle East, Russia and President Obama's legacy, Baker Institute for Public Policy Issue Brief, 19 January. https://scholarship.rice.edu/bitstream/handle/1911/93927/BI-Brief-011917ObamaFPLegacy.pdf?sequence=1\&isAllowed=y. Accessed 20 January 2018.

Bouzarovski, S. and Bassin, M. (2011). Energy and identity: Imagining Russia as a hydrocarbon superpower. Annals of the Association of Amercian Geographers 101(4): 783-794.

Borshchevskaya, A. (2016). The maturing of the Israeli-Russian relationship. Washingto Institute Policy Paper. http://www.washingtoninstitute.org/policyanalysis/view/the-maturing-of-israeli-russian-relations. Accessed 20 January 2018.

Brown, L. C. (1984). International Politics and the Middle East: Old Rules, Dangerous Game, London: I. B. Tauris.

Chernenko, E. and Yusin, M. (2012). Kremlin wall stands behind Syria. Kommersant, 17 July.

Dannreuther, R (2010). Russian discourses and approaches to Islam and islamism. R. Dannreuther and L. March (eds). Russia and Islam: State Society and Radicalism. London: Routledge: 9-25.

Dannreuther R. (2012). Russia and the Middle East: A cold war paradigm?. EuropeAsia Studies, 64(3): 543-560. 
Dannreuther, R. (2015). Russia and the Arab Spring: Supporting the counterrevolution. Journal of European Integration 37(1): 77-94.

Demchenko, A (2012). Arab Spring and Russian Policy in the Middle East.

Perspectivy.

http://www.perspektivy.info/rus/desk/arabskaja_vesna_i_politika_rossii_v_blizhnevos tochnom_regione_2012-09-15.htm. Accessed 13 January 2018.

Deyermond, R. (2016). The uses of sovereignty in twenty-first century Russian foreign policy. Europe-Asia Studies 68(6): 957-984.

Fish, M. S. (2017). What is Putinism? Journal of Democracy 28(4): 61-75.

Fitzpatrick, C. A. (2016) How many Russians are fighting for ISIS? A brief history of the Kremlin's arbitrary numbers. The Interpreter.

http://www.interpretermag.com/how-many-russians-are-fighting-for-isis-a-briefhistory-of-the-kremlins-arbitrary-numbers/. Accessed 10 January 2018.

Fitzpatrick, D. D. (2017). In snub to U.S., Russia and Egypt move toward deal on air bases. New York Times, 30 November.

Gerges, F. A. (2013). The Obama approach to the Middle East: The end of America's moment. International Affairs 89(2): 299-323.

Grigoriev, E. (2011). Today Libya: Tomorrow everywhere. Nezavisimaya gazeta, 21 March.

Hannah, J. (2016). Russia's Middle East offensive: Russia's star is waxing while America's wanes. Foreign Policy, 13 September.

http://foreignpolicy.com/2016/09/13/russias-middle-east-offensive/. Accessed 20 January 2018.

Hutcheson, D. S. and Petersson, B. (2016). Short-cut to legitimacy: Popularity in Putin's Russia. Europe-Asia Studies, 68(7): 1107-1126.

INSOR (2010). Russia and the 21 ${ }^{\text {st }}$ Century; Sketch of the Desired Future. Moscow: Institute for Contemporary Development.

Ivanov. I. S. (ed.) (2013a). Russia and the "New Elites" of the countries of the "Arab Spring”: Possibilities and perspectives on cooperation. Moscow: Russian Council on International Affairs.

Ivanov, I. S. (2013b). Russia and the Greater Middle East. Moscow: Russian Council of International Affairs.

Ivanov, M. and Kozlov, D. (2011). Resolution is ripe for Russia. Kommersant, 22 March. 
Ivanov, S. (2008). Where is Russia heading? New vision of pan-European security. https://www.highbeam.com/doc/1P2-15324155.html. Accessed 10 January 2018.

Katz, M. N. (2016a). Understanding Syria's many conflicts. E-International Relations, 31 August. http://www.e-ir.info/2016/08/31/understanding-syrias-manyconflicts/. Accessed on 20 January 2018.

Katz, M. N. (2016b). Russian-Iranian relations: Troubled ties. Lobelog. https://lobelog.com/russian-iranian-relations-troubled-ties/. Accessed 10 January 2018.

Kennedy, P. (1987). The Rise and Fall of Great Powers. New York: Random House.

Kozhanov, N. (2016). Russia's foothold in Iran: Why Tehran changes its mind.

Carnegie Moscow Centre Commentary, 5 September.

http://carnegie.ru/commentary/64471. Accessed 20 January 2018.

Levada (2015) Net approval levels of Putin and Medvedev, 2010-2014. http://www.levada.ru/indeksy. Accessed 20 July 2015.

Lukmanov, A. (2013). Russian Muslims and the "Arab Spring”. International Affairs, 59(2): 101-116.

Mandour, M. (2016). Egypt's shift from Saudi Arabia to Russia. Carnegie Endowment, Sana Middle East Analysis, 3 November.

http://carnegieendowment.org/sada/65030. Accessed 10 February 2018.

Montefiore, S. S. (2015). Putin's imperial adventure in Syria. New York Times, 9

November. https://www.nytimes.com/2015/10/09/opinion/putins-imperial-adventurein-syria.html. Accessed 13 February 2018.

Naumkin, V. (2006). Evroislam kak naslednik dzhadidizma. D. V. Mukhetdinova, ed., Forumy Rossiskykh musul'man na poroge novogo tysyacheletiya. Nizhnii

Novgorod: Medina.

Oliker, O., Crane, K., Scwartz, L. H., and Yusupov, C. (2009). Russian Foreign Policy: Sources and Implications. Santa Monica, CA: RAND Corporation. https://www.rand.org/content/dam/rand/pubs/monographs/2009/RAND_MG768.pdf. Accessed 10 January 2018.

Putin, V. (2015) Speech delivered to the 70th session of the United Nations General Assembly, New York.

https://www.washingtonpost.com/news/worldviews/wp/2015/09/28/read-putins-u-ngeneral-assembly-speech/?utm_term=.04d6e30409bf. Accessed 10 January 2018.

Putin V. (2013) Putin talks NSA, Syria, Iran, drones in Russian television Interview in http://rt.com/news/putin-rt-interview-full-577/. Accessed 20 January 2018. 
Putin, V. (2012). Russia and the Changing World. Rossiskaya gazeta.

http://www.rg.ru/2012/02/27/putin-politika.html. Accessed 10 January 2018.

Robinson, N. (2017). Russian neo-patrimonialism and Putin's 'cultural turn'. EuropeAsia Studies 69(2): 348-366.

Rutland, P. (2008). Russia as an energy superpower. New Political Economy, 13(2): 203-10.

Sakwa, R. (2014). Putin Redux: Power and Contradiction in Contemporary Russia. London: Routledge.

Samarina, A. (2011). Tandem Tests Strength before 2012 Election. Nezavisimaya gazeta, 23 March.

Sladden, J., Wasser, B., Connable, B., and Grand-Clement, S. (2017). Russian Strategy in the Middle East. Santa Monica CA; Rand Corporation. https://www.rand.org/pubs/perspectives/PE236.html. Accessed 10 January 2018.

Sokolov, M. (2011). Is Russia threatened by a popular revolution as in the Arab Countries. http://www.svobodanews.ru/content/transcript/2323664. Accessed 6 June 2013.

Surkov, V. (2006). Sovereignty: It is a political synonym for competitiveness'. N. Garadzha (ed.), Sovereignty. Moscow: Evropa.

Suslov, D. (2012). Arab Revolutions and Russian-US Relations. http://www.hse.ru/data/2011/04/27/1210609292/Apace\%20peo\%20\%20P-CA.pdf Accessed 15 August 2014.

Stepanova, E. (2016). Russia in the Middle East: Back to a 'grand strategy' - or enforcing multilateralism. Politique Etrangère, 2: 23-35.

Trenin, D. (2018). What is Russian up to in the Middle East? Cambridge: Polity.

Trenin, D. (2017). Russia and Iran: Historic mistrust and contemporary partnership. Carnegie Moscow Centre. http://carnegie.ru/2016/08/18/russia-and-iran-historicmistrust-and-contemporary-partnership-pub-64365. Accessed 10 January 2018)

Tsygankov, A. (2013). La Russie et le moyen-orient: Entre islamisme et occidentalisme. Politique Etrangère 78(1): 79-91.

Tsygankov, A. P. (2016). Crafting the state-civilisation: Vladimir Putin's turn to distinct values. Problem of Post-Communism 63(3): 146-158.

Zvyagelskaya, I. (2016). Russia, the new protagonist in the Middle East. A. Ferrari (ed.) Putin's Russia: Really Back? Milan: Italian Institite for International Political Studies: 73-91. 
